\title{
Analisis Kemampuan Multirepresentasi Verbal dan Gambar terhadap Mahasiswa Semester 1 dalam Memahami Konsep Teknologi Solar Cell
}

\author{
Elsa Munawarotul Jannah ${ }^{1^{*}}$, Sudarti $^{1}$ \\ ${ }^{1}$ Program Studi Pendidikan Fisika, FKIP Universitas Jember, \\ Jember 68121, Indonesia \\ *e-mail:180210102081@students.unej.ac.id
}

Received: 03 Mei 2020. Accepted: 28 Juni 2020. Published: Juli 2020

\begin{abstract}
Abstrak
Penelitian ini bertujuan untuk menganalisis kemampuan multirepresentasi verbal dan gambar pada mahasiswa semester 1 dalam memahami konsep teknologi solar cell. Penelitian menggunakan metode deskriptif dengan instrumen berupa kuisioner pada 40 mahasiswa. Sumber data diperoleh dari kuisioner berbentuk pilihan ganda yang meliputi soal verbal dan gambar sebanyak 8 soal yang tervalidasi. Hasil jawaban dianalisis untuk mendeskripsikan kemampuan mahasiswa semester 1 dalam merepresentasikan konsep energi terbarukan dan teknologi solar cell dalam bentuk verbal dan gambar. Hasil analisis data menunjukkan bahwa kemampuan representasi verbal lebih rendah daripada representasi dalam bentuk gambar yaitu $18,75 \%$ untuk representasi verbal dan 32,5\% untuk representasi gambar. Nilai persentase representasi verbal dan gambar mahasiswa belum mencapai 50\%, hal ini dikarenakan mahasiswa semester 1 belum menempuh mata kuliah fisika lingkungan sehingga hanya mengingat materi tentang konsep teknologi solar cell yang telah diajarkan di SMA.
\end{abstract}

Kata Kunci: multirepresentasi, verbal dan gambar, teknologi solar cell

\section{Analysis of Multirepresentation Verbal and Image Abilities of Semester $I^{\text {st }}$ Students In Understanding The Concept of Solar Cell Technology}

\begin{abstract}
This study aims to analyze the ability of verbal and image multi-representation in semester 1 students in understanding the concept of solar cell technology. The research used descriptive method with an instrument in the form of a questionnaire to 40 students. The data source was obtained from a questionnaire in the form of multiple choices which included validated verbal and image questions. The results of the answers were analyzed to describe the ability of 1st semester students to represent the concept of renewable energy and solar cell technology in verbal and image forms. The results of the data analysis show that the ability of verbal representation is lower than that in the form of pictures, with a percentage of $18.75 \%$ for verbal representation and $32.5 \%$ for image representation. The percentage value of students' verbal and pictorial representations has not reached 50\%, this is because semester 1 students have not taken environmental physics courses so they only remember the material about the concept of solar cell technology that has been taught in high school.
\end{abstract}

Keywords: multirepresentation, verbal and pictures, solar cell technology.

PENDAHULUAN
Fisika Lingkungan merupakan mata kuliah yang harus ditempuh oleh mahasiswa pendidikan fisika, Fakultas 
Keguruan dan Ilmu Pendidikan Universitas Jember. Mata Kuliah ini membahas materi tentang implementasi ilmu fisika di lingkungan seperti konsep teknologi solar cell atau sel surya. Sel surya merupakan salah satu sumber energi terbarukan yang ramah lingkungan. Sel surya merupakan komponen yang mampu mengkonversi energi matahari menjadi energi listrik, dengan prinsip yang disebut efek photovoltaic. Sel surya konvensional beroperasi dengan menggunakan prinsip semikonduktor $p-n$. Semikonduktor tipen memiliki kelebihan elektron yang bermuatan negatif sedangkan semikonduktor tipe-p memiliki kelebihan hole yang bermuatan positif dalam struktur atomnya. Cara kerja dari solar cell yaitu dengan menggunakan efek photovoltaic (photo berarti cahaya dan voltaic berarti tegangan) berupa sel surya yang terbuat dari silikon kristal tunggal. Efek fotovoltaik merupakan fenomena terjadinya tegangan listrik karena adanya interaksi dua elektrode yang dihubungkan dengan sistem padatan dan cairan saat mendapat energi berupa cahaya matahari. Cahaya matahari tersebut membawa energi yang kemudian diserap oleh sel dan diserap kembali ke dalam semikonduktor sehingga memicu pergerakan elektron dalam semikonduktor tersebut. Elektron bebas yang dipicu oleh energi cahaya akan bergerak menuju arah tertentu. Elektron yang mengalir ini disebut arus listrik (Santosa, 2014).

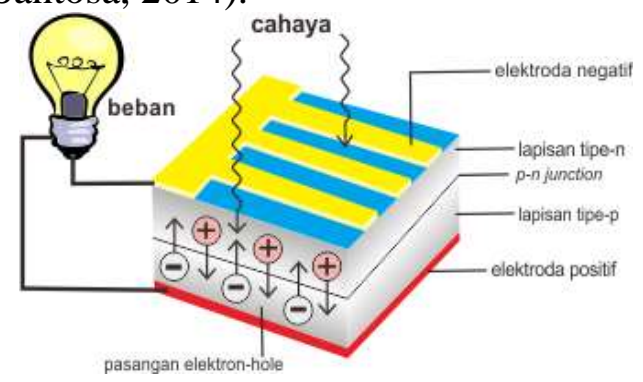

Gambar 1. Efek fotovoltaik

Energi surya diubah secara langsung menjadi bentuk energi lain dengan tiga proses terpisah, yaitu proses fotosintesis, proses fotoelektrik atau konversi energi dalam bentuk listrik, dan proses penyerapan radiasi dalam bentuk suhu. Teknologi sel surya ini termasuk ke dalam kategori proses helioelektrik, yaitu konversi energi matahari dalam bentuk listrik. Proses ini terjadi jika menggunakan fotovoltaik. Fotovoltaik merupakan komponen yang digunakan untuk mengkonversi energi matahari menjadi energi listrik searah. Fotovoltaik ini terbuat dari bahan semikonduktor seperti silikon $(\mathrm{Si})$. Sistem penyimpanan energi perlu memperhitungkan fotovoltaik dan kapasitas dari baterai, dengan probabilitas keadaan radiasi matahari, karena energi listik yang dihasilkan dari matahari tidak bisa bertahan secara terus-menerus. Hal ini disebabkan oleh penyinaran matahari rata-rata 12 jam sehari. Menurut Santosa (2014:109) posisi sel surya terhadap matahari dapat membawa pengaruh terhadap intensitas energi listrik yang dihasilkan. Energi listrik yang dihasilkan sel surya ditampung ke dalam baterai sehingga simpanan energi listrik dalam baterai tersebut dapat dipakai untuk keperluan tertentu. Hingga saat ini, perkembangan teknologi solar cell berhasil dilakukan oleh para peneliti untuk mendapatkan solar cell yang mempunyai efisiensi tinggi, ekonomis dan terjangkau (Sutrisno, 2012).

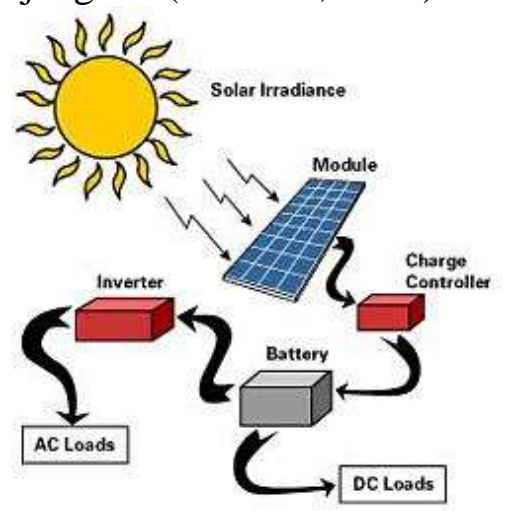

Gambar 2. Proses fotovoltaik

Generasi Pertama, teknologi pertama menggunakan material berupa 
silikon berkristal tunggal sehingga dapat memperoleh solar cell dengan efisiensi yang baik. Akan tetapi untuk biaya produksi komersial cukup mahal sehingga menjadi kurang efisien jika dijadikan sebagai sumber energi alternatif. Teknologi yang kedua ini menggunakan wafer silikon polikristal yang dibuat dengan teknologi casting. Pada teknologi ini, solar cell lebih ekonomis walaupun efisiensinya lebih rendah daripada sel surya yang menggunakan bahan silikon berkristal tunggal.

Generasi Kedua, adalah solar cell dengan teknologi lapisan tipis (thin film) yang hanya menggunakan kurang dari $1 \%$ dari bahan pokok berupa silikon. Keunggulan dalam memanfaatkan tipe thin film yaitu semikonduktor sebagai lapisan solar cell bisa digerakkan terhadap substrat yang elastis hingga menghasilkan sel surya yang fleksibel. Permasalahannya adalah bahan baku ini belum dapat diterima dengan baik karena mengandung unsur kimia yaitu Cd. Jika dipasang di atap rumah maka sel surya CdTe akan terbakar. Hal ini disebabkan karena unsur Cadmium dapat memicu adanya polusi yang sangat berbahaya.

Generasi Ketiga, yaitu teknologi solar cell dari bahan polymer, disebut dengan sel surya organik. Sel Surya organik dibuat dari semikonduktor organik seperti polyphenylene vinylene dan fullerene. Sel surya generasi ketiga ini masih memiliki permasalahan dalam hal efisiensi dan usia aktif sel yang singkat, solar sel jenis ini dapat berpengaruh signifikan pada satu dekade mendatang karena harga dan proses pembuatannya akan relatif terjangkau.

Konsep teknologi solar cell dapat dijelaskan secara multirepresentasi, yaitu dengan menerapkan berbagai jenis representasi seperti verbal dan gambar. Representasi verbal adalah penyajian permasalahan tertentu dalam bentuk kalimat-kalimat bahasa, sedangkan representasi gambar adalah penyajian permasalahan tertentu dalam bentuk gambar. Menurut Ainsworth (2006), penyajian multirepresentasi mempunyai tiga fungsi penting. Pertama, representasi sebagai pelengkap informasi dalam proses kognitif (pengetahuan). Kedua, dapat menekan peluang terjadinya kesalahan interpretasi dari representasi lainnya, sehingga multirepresentasi dapat mendorong mahasiswa untuk menguatkan pemahaman terhadap suatu situasi secara mendalam. Kemampuan multirepresentasi ini dapat diterapkan dalam mempelajari mata kuliah fisika lingkungan. Kemampuan multirepresentasi mahasiswa perlu dianalisis lebih awal agar kemampuan mahasiswa dapat diidentifikasi dan segera dilakukan evaluasi, tetapi jika sudah tinggi maka perlu ditingkatkan lagi melalui strategi pembelajaran yang efisien (Rahmanita, 2017).

Bersadarkan hasil rujukan persoalan di atas, telah dilakukan penelitian tentang analisis kemampuan multirepresentasi verbal dan gambar terhadap mahasiswa semester 1 dalam memahami konsep teknologi solar cell.

\section{BAHAN DAN METODE}

Penelitian ini menggunakan metode deskriptif dengan melibatkan sampel sebanyak 40 Mahasiswa semester 1 Pendidikan Fisika, Fakultas Keguruan dan Ilmu Pendidikan Universitas Jember. Metode deskriptif merupakan suatu metode yang bertujuan untuk memberikan gambaran sampel dari data yang didapatkan dan membuat kesimpulan yang berlaku secara umum (Sugiyono, 2009). Sumber data diperoleh dari kuisioner berbentuk pilihan ganda 


\section{Analisis Kemampuan Multirepresentasi...Jupiter...Vol 2 No 1...Juli 2020...1-6 Elsa Munawarotul Jannah, Sudarti}

yang meliputi soal verbal dan gambar sebanyak 8 soal yang tervalidasi. Instrumen penelitian diambil dari beberapa soal ujian nasional serta beberapa soal yang dikembangkan sendiri oleh peneliti. Sebagian instrumen menyajikan representasi verbal, sebagian lainnya representasi gambar. Data yang diperoleh dari jawaban mahasiswa kemudian dianalisis dengan melihat skor benar dan salah.

\section{HASIL DAN PEMBAHASAN}

Hasil penelitian menunjukkan bahwa nilai kuisioner yang diperoleh dari 40 mahasiswa semester 1 Pendidikan Fisika, Fakultas Keguruan dan Ilmu Pendidikan Universitas Jember dapat dilihat pada Tabel 1 .

Tabel 1. Persentase Skor Kuisioner Multirepresentasi Verbal dan Gambar

\begin{tabular}{ccc}
\hline $\begin{array}{c}\text { Jenis } \\
\text { Pertanyaan }\end{array}$ & $\begin{array}{c}\text { Nomor } \\
\text { Pertanyaan }\end{array}$ & Presentase \\
\hline \multirow{3}{*}{ Verbal } & 1 & $15,0 \%$ \\
& 2 & $10,0 \%$ \\
& 3 & $15,0 \%$ \\
Gambar & 4 & $35,0 \%$ \\
& 5 & $55,0 \%$ \\
& 6 & $15,0 \%$ \\
& 7 & $35,0 \%$ \\
& 8 & $25,0 \%$ \\
\hline
\end{tabular}

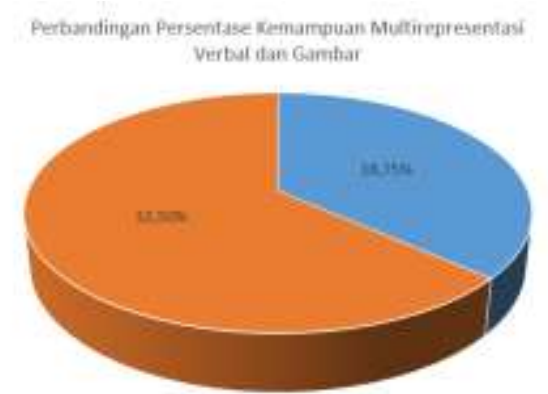

Gambar 3. Grafik persentase perbandingan rata-rata nilai multirepresentasi verbal dan gambar

Berdasarkan data pada Tabel 1 dapat diketahui bahwa persentase jawaban benar yang diberikan oleh mahasiswa semester 1 sedangkan Gambar 3 menjelaskan persentase perbandingan rata-rata nilai yang dari soal yang memuat tentang multirepresentasi verbal dan multirepresentasi gambar dengan nilai persentase beruturt-turut adalah 18,75\% dan $32,5 \%$. Adanya perbedaan ini dapat diketahui bahwa kemampuan multirepresentasi gambar lebih tinggi daripada multirepresentasi verbal.
Berdasarkan data yang diperoleh pada Tabel 1 berupa persentase nilai jawaban benar yang diberikan oleh mahasiswa pendidikan fisika semester 1 , Fakultas Keguruan dan Ilmu Pendidikan Universitas Jember pada soal kuisioner yang telah diberikan. Pada kuisioner tersebut, nomor 1, 2, 3, 4 dan 8 memuat soal representasi verbal sedangkan nomor 5, 6, 7, dan 9 memuat soal representasi gambar. Nilai rata-rata represesntasi mahasiswa pada format verbal mencapai $18,75 \%$ dengan nilai rata-rata dari setiap soal berturut-turut memiliki nilai persentase $15 \%, 10 \%, 15 \%$, dan $35 \%$, 
sedangkan nilai rata-rata representasi pada format gambar mencapai 32,5\% dengan nilai dari rata-rata setiap soal berturut-turut memiliki nilai persentase $55 \%, 15 \%, 35 \%$ dan $25 \%$ sehingga dapat dikaterogikan bahwa kemampuan representasi mahasiswa pada format gambar terhadap konsep teknologi sel surya tergolong lebih tinggi daripada kemampuan representasi verbal. Representasi verbal digunakan untuk mendiskripsikan definisi dari suatu konsep sedangkan kuantitas dan konsepkonsep yang bersifat fisik dapat lebih mudah dipahami dengan cara divisualisasikan (Irwandani, 2014: 2). Hal ini sesuai dengan hasil penelitian bahwa representasi gambar dalam konsep yang berifat fisik seperti konsep teknologi solar cell dapat lebih mudah dipahami oleh mahasiswa pendidikan fisika semester 1, Fakultas Keguruan dan Ilmu Pendidikan Universitas Jember. Nilai rata-rata dari analisis kemampuan multirepresentasi yang didapatkan pada penelitian ini masih belum mencapai $50 \%$, hal ini dikarenakan mahasiswa semester 1 masih belum menempuh mata kuliah fisika lingkungan, mahasiswa hanya sebatas mengingat mata pelajaran fisika yang ditempuh pada saat SMA tentang konsep teknologi solar cell pada materi energi terbarukan, maka perlu adanya proses pemberian informasi dan pengetahuan mendalam tentang konsep teknologi solar cell kepada mahasiswa semester 1 sebelum dilakukannya penelitian.

\section{KESIMPULAN}

Berdasarkan hasil analisis di atas, dapat di ambil kesimpulan sebagai berikut:

1. Representasi verbal mahasiswa pendidikan fisika semester 1, Fakultas Keguruan dan Ilmu Pendidika Universitas jember masih tergolong rendah daripada representasi gambar, yaitu dengan perbandingan persentase yang dihasilkan pada penelitian ini adalah $18,75 \%$ untuk representasi verbal dan $32,5 \%$ untuk representasi gambar.

2. Nilai persentase dari kemampuan multirepresentasi mahasiswa semester 1 dalam memahami konsep teknologi solar cell belum mencapai $50 \%$ karena mahasiswa semester 1 belum menempuh mata kuliah fisika lingkungan sehingga hanya sebatas mengingat materi tersebut yang telah diajarkan di SMA.

\section{DAFTAR PUSTAKA}

Siroj, S.A. (2017). Fikih Energi Terbarukan. Jakarta: Kemala

Ainsworth, S. 2006. DeFT: A Conceptual Framework for Considering Learning with Multiple Representations. Learning and Instruction. 16: 183 - 198.

Andromeda, B., Tomo D, dan Haratua T.M.S. 2017. Analisis Kemampuan Multirepresentasi Siswa Pada Konsep-Konsep Gaya Di Kelas X SMA Negeri 3 Pontianak. Untan. 116.

Indrawani. 2014. Multi Representasi Sebagai Alternatif Pembelajaran Dalam Fisika. Jurnal Al Biruni 3. 110.

Lubis, Abubakar. 2007. Energi Terbarukan dalam Pembangunan Berkelanjutan. Jurnal Teknik Lingkungan. 2(8): 155-162.

Santosa, AWB, Mulyanto P. 2014. Pemanfaatan Tenaga Angin dan Surya sebagai Alat Pembangkit Listrik pada Bagan Perahu. Jurnal Kapal. 11(3): 108 - 116

Rahmatina, D. I., Sutopo, dan Wartono. 2017. Pemahaman dan Kemampuan 
Analisis Kemampuan Multirepresentasi...Jupiter...Vol 2 No 1...Juli 2020...1-6 Elsa Munawarotul Jannah, Sudarti

Multirepresentasi Siswa SMA pada Materi Usaha-Energi. Prosiding Seminar Pendidikan IPA Pascasarjana UM. (2): 127 - 133.

Sanjaya, L.A., Agus Setyo Budi, dan Made Astra. 2016. Pengembangan Alat Peraga Energi terbarukan. Prosiding Semiar Nasional Fisika (EJournal) SNF2016. (5): 45-48
Sutrisno. 2012. Teknologi Sel Surya Menyongsong Industri Sel Surya di Indonesia. PT. Len Industri Persero. https://www.len.co.id/teknologi-selsurya-menyongsong-industri-selsurya-di-indonesia/. Diakses tanggal 1 November 2020. 